\title{
Artículos
}

\section{Forest restoration after alluvial gold mining can recover vegetation structure. A case study in Colombia}

\section{La restauración forestal después de la minería aluvial de oro puede recuperar la estructura de la vegetación. Estudio de caso en Colombia}

\author{
Sergio Esteban Lozano-Baez $\mathbb{C}_{\square}$, José Ignacio Barrera-Cataño ${ }^{\square}$, \\ Ricardo Ribeiro Rodrigues ${ }^{\square} \square$, Yamileth Domínguez-Haydar ${ }^{\circledR} \square$, Paula Meli ${ }^{\circledR} \square$
}

\begin{abstract}
Technical reclamation and spontaneous succession (passive restoration) are the two main approaches for restoring post-mining sites worldwide. Despite substantial differences between both approaches, little is known regarding how they differ in terms of ecological outcomes. We assessed and compared the vegetation structure and composition in one spontaneous succession forest that is 29 years old, two technically reclaimed forests that are 2 and 10 years old after alluvial gold mining, and one old-growth reference forest in northeastern Antioquia, Colombia. We sampled trees and saplings establishing three Modified-Whittaker Plots in each site. We measured tree basal area, canopy cover, vegetation height, tree density, and species richness. Vegetation structure and composition differed considerably among restoration approaches. Species richness was significantly greater in the spontaneous succession forest than at the other sites. Similarly, technical reclamation significantly increased the vegetation attributes after 10 years, reaching values similar to the reference forest. We underscore the importance of fast-growth planted species (Acacia mangium, Samanea saman, and Schizolobium parahyba) to revegetate mining degraded lands.
\end{abstract}

Key words: Acacia mangium. Active restoration. Passive restoration. Samanea saman. Schizolobium parahyba.

\section{Resumen}

Mundialmente, la recuperación técnica y la sucesión espontánea (restauración pasiva) son los dos principales enfoques para restaurar áreas post-minería. A pesar de las diferencias sustanciales entre ambos enfoques, sabemos poco sobre cómo difieren en términos de resultados ecológicos. Evaluamos y comparamos la estructura y composición de la vegetación en un bosque con sucesión espontánea con 29 años, dos bosques técnicamente recuperados que tienen 2 y 10 años después de la extracción de oro aluvial, y un bosque de referencia en el noreste de Antioquia, Colombia. En cada sitio establecimos tres parcelas tipo Whittaker modificadas. Medimos el área basal de los árboles, cobertura del dosel, altura de la vegetación, densidad de árboles y riqueza de especies. La estructura y composición de la vegetación difirieron considerablemente entre los enfoques de restauración. La riqueza de especies fue significativamente mayor en el bosque de sucesión espontánea. Asimismo, la recuperación técnica incrementó significativamente los atributos de la vegetación. Adicionalmente, destacamos la importancia de las especies plantadas de rápido crecimiento (Acacia mangium, Samanea saman y Schizolobium parahyba) para revegetar zonas mineras degradadas.

Palabras clave: Acacia mangium. Restauración activa. Restauración pasiva. Samanea saman. Schizolobium parahyba. 


\section{Introduction}

Surface mining covers almost $1 \%$ of the world's land, producing drastic changes in the landscape and soil profile (Bridge, 2004; Zhen et al., 2015; Sigcha et al., 2018). The mining industry represents the main driver in the economy of many tropical and temperate regions. In Colombia, gold mining is expanding due to government programs that provide incentives (Betancur-Corredor et al., 2018). For instance, legal mining titles increased from 1316 in 2001 to 6952 in 2018 (González-González et al., 2021). In particular, alluvial gold-exploitations in Colombia extend over 100 (9\%) of the country's 1122 municipalities, covering a total of 92046 ha. Historically, Antioquia is one of the most affected departments by the alluvial gold-exploitations. In this region, natural ecosystems have been intensively degraded (Ministry of Mines and Energy 2019), changing the hydrologic connectivity, and the vegetation structure and composition (Villa \& Tobón, 2012), as in other areas in the department of Chocó (Valois-Cuesta \& Martínez-Ruiz, 2016).

During the last decades, many forest restoration projects reclaiming mined lands have been implemented in Colombia (Arias-Escobar \& Barrera-Cataño, 2007; Ayala et al., 2008; Betancur-Corredor et al., 2018; Domínguez-Haydar \& Armbrecht, 2011; Ramírez \& Rangel-Ch., 2019; Valois-Cuesta et al., 2017). These projects have used two main approaches: (1) technical reclamation, through adopting technical measures such as planting trees; (2) spontaneous succession or passive restoration without any human intervention (Tropek et al., 2012). According to a recent study (González-González et al., 2021), the technical reclamation approach is rarely used in Colombia, and only $21 \%$ of the mining concessions carry out reforestation actions. Each approach can create a different vegetation structure and composition in the ecosystems. Therefore, to understand the possible outcomes of both types of restoration approaches more studies are necessary (Jones et al., 2018; Prach \& Hobbs, 2008; Šebelíková et al., 2016). Specifically, the development of vegetation after alluvial gold mining has been poorly studied in Colombia. Recently, the plant communities were characterized at three abandoned mining sites that are 30,15 , and 5 years old in the municipality of Condoto (Chocó), showing that after 30 years the vegetation structure is entirely different from the reference forest, and floristic composition reached $50 \%$ of its initial conditions (Ramírez \& Rangel-Ch., 2019). Likewise, soil seed bank formation (Valois-Cuesta et al., 2017) and pioneer plant species (Valois-Cuesta \& Martínez-Ruiz, 2017) during early revegetation of areas affected by gold mining have also been studied in Chocó, as well as the vulnerability of the forests in the Chocó to the loss of plant species as a result of alluvial gold and platinum mining (Valois-Cuesta \& Martínez-Ruiz, 2016).

In this study, we compare the early outcomes of spontaneous succession and technical reclamation after alluvial gold-exploitation in Northeast Antioquia, Colombia. We also compare the structure and composition of the vegetation in the spontaneous succession and technical reclamation with an old-growth reference forest near the study region. We hypothesized that technical reclamation, with the plantation of one exotic (Acacia mangium) and two native species (Samanea saman and Schizolobium parahyba) after 10 years would recover the vegetation structure and composition, reaching similar values when compared to the reference forest. As the spontaneous succession site has 29 years under the natural regeneration process, we also hypothesized that vegetation attributes would be higher than the technical reclamation site.

\section{Materials and Methods}

\section{Site Description}

The study area is in the municipalities of El Bagre $\left(7^{\circ} 35^{\prime}\right.$ $\left.47^{\prime \prime} \mathrm{N}, 74^{\circ} 48^{\prime} 40^{\prime \prime} \mathrm{W}\right)$ and Zaragoza ( $7^{\circ} 29^{\prime} 23^{\prime \prime} \mathrm{N}, 74^{\circ}$ $52^{\prime} 03^{\prime \prime} \mathrm{W}$ ) in northeastern Antioquia, Colombia, in the basin of the Nechí River (Figure 1A). The region is characterized by an average temperature of $28^{\circ} \mathrm{C}$ and an average annual rainfall between 2000 and $4000 \mathrm{~mm}$. The average elevation is $80 \mathrm{~m}$ and the topography is mostly flat with alluvial plains (Ministerio del Trabajo, 2013). The region was originally covered by humid tropical forests, but the current landscape is highly fragmented because of mining tradition that dates back to the prehispanic period. Since the middle of the 20th century, the greater part of the gold is mined by digging dredges (Villa \& Tobón, 2012). The greatest environmental impacts of this process occur during the operational phase, when vegetation, wildlife, and upper soil are removed. Then, one dredge is used to dig up the deep alluvium material at depths of 20-30 m, which contains the gold deposits. Currently, in these municipalities, 12 000 ha are affected by alluvial gold mining (Ministry of Mines and Energy, 2019).

Within this landscape the restoration approaches of spontaneous succession and technical reclamation have been implemented by the Colombian mining company 
Mineros S.A. Initially, the spontaneous succession approach was implemented until the 1980s when little attention was carried out to recover post-mining sites, there was no dredging plan, and mining wastes were abandoned in mountains with slopes greater than $20 \%$. Our site named Caño La 3, with 29 years of spontaneous succession, represents this practice (hereafter SS). The technical restoration approach emerged in 2000, when technical measures were established by the company. The technical reclamation aims to preserve native flora and fauna while supporting settlers through the establishment of agroforestry parcels (Mineros S.A., 2019).

(A)
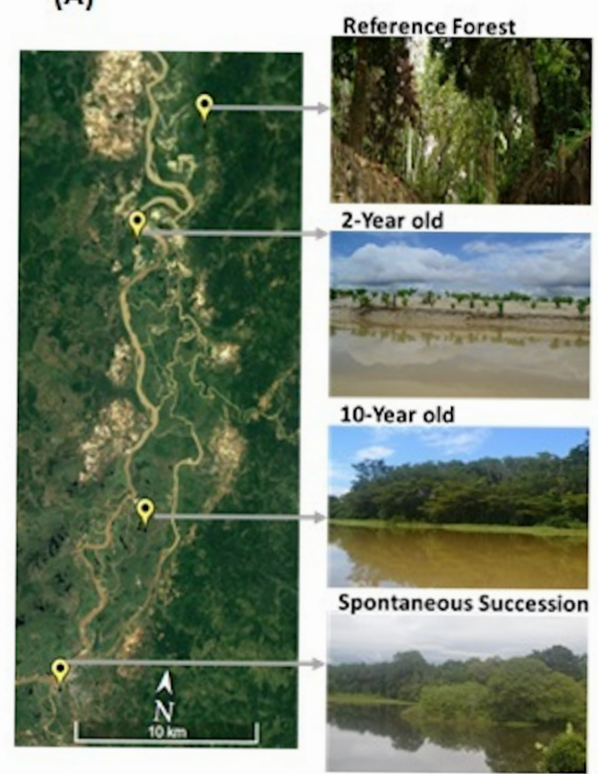

(B)

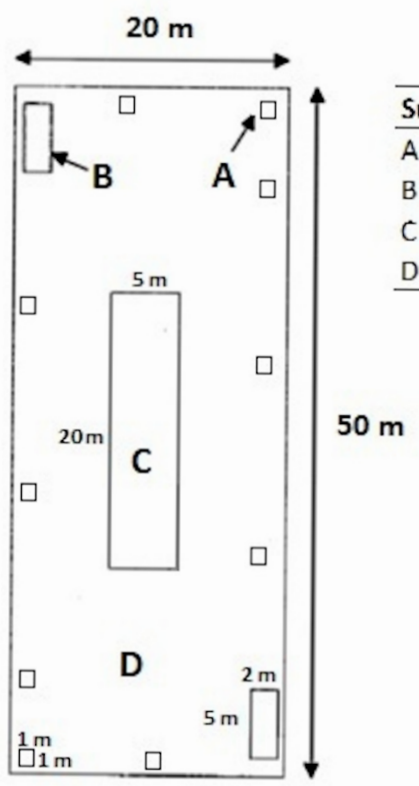

(C)

\begin{tabular}{llr}
\hline Subplot & Vegetation criteria & Area m2 \\
\hline A & Herbaceous cover & 1 \\
B & $D B H \geq 1 \mathrm{~cm}$ & 10 \\
C & $D B H \geq 5 \mathrm{~cm}$ & 100 \\
D & $D B H \geq 10 \mathrm{~cm}$ & 1000 \\
\hline
\end{tabular}

Figure 1. A. An aerial photograph of the Nechí River floodplain in Northeast Antioquia, Colombia. Pictures show the vegetation for each study site; B. Modified Whittaker plot design; C. nested subplot description. 
The agroforestry model includes the establishment of crops, as well as the training of the local community to produce compost and establish nurseries with plant species selected for the reclamation process (Betancur-Corredor et al., 2018). This approach follows a technical reclamation plan, stabilizing and profiling the waste generated by mining. The new ecosystems have stable slopes (e. g., less than 15\%), where exotic (A. mangium) and native species (S. saman and S. parahyba) are planted. These species are fast-growth, nitrogen fixatives, and provide abundant litter (Thomas, 2014). With this technical reclamation approach, we selected forests between 2 and 10 years old. We took as a reference the natural forest named Sabalito (hereafter RF). Although there was no evidence of human disturbances in the RF now, according to interviews, in the early 20th century this site was partially cleared at least once for agricultural purposes.

\section{Vegetation Sampling}

We conducted vegetation sampling during June-July 2012. In each site, we established three $1000 \mathrm{~m} 2 \mathrm{Mo}-$ dified-Whittaker plots $(50 \times 20 \mathrm{~m}$; Stohlgren et al., 1995). Each Modified-Whittaker plot consisted of a series of nested subplots (Figure 1B) to measure vegetation attributes at different levels: In ten $1 \mathrm{~m} 2$ (1 $11 \mathrm{~m})$, we measured herbaceous cover. In two 10 $\mathrm{m} 2$ plots $(2 \times 5 \mathrm{~m})$, we recorded all individuals (trees or shrubs) with a diameter at breast height $(\mathrm{DBH}) \geq 1$ $\mathrm{cm}$. In one $100 \mathrm{~m} 2$ plot, we measured the individuals with $\mathrm{DBH} \geq 5 \mathrm{~cm}$. The individuals with $\mathrm{DBH}$ between 1 and $5 \mathrm{~cm}$ were classified as saplings. Finally, we measured trees with $\mathrm{DBH}>10 \mathrm{~cm}$ in the whole 1000 $\mathrm{m} 2$ plot (Figure 1C). This sampling allowed us to collect a large area and detect less abundant plant species (Stohlgren et al., 1998; Anderson \& Hoffman, 2007; Firincioğlu et al., 2007).

In each study site, we measured the following vegetation attributes: (1) tree basal area; (2) canopy cover; (3) vegetation height; (4) tree density; and (5) species richness. These are key ecological indicators useful to evaluate vegetation structure and composition in tropical forest restoration projects (Chaves et al., 2015; Lozano-Baez et al., 2019; Viani et al., 2018). We measured the percentage of canopy cover in each plot by an adaptation of the line interception method (Canfield, 1941), installing a $50 \mathrm{~m}$ transect in the middle of each plot. We measured the vegetation height with a $5 \mathrm{~m}$ measuring stick, and the remaining height of trees taller than this was estimated visually.

Table 1. Vegetation attributes (mean \pm standard error, $n=3$ ) sampled in the reference forest (RF), spontaneous succession (SS), and two technically reclaimed sites of different ages (2 and 10 years old) after surface mining, in northeastern Antioquia, Colombia. Different superscript letters denote statistically significant differences $(p<0.05)$ between land cover types.

\begin{tabular}{lllll} 
& RF & SS & $10-$ Year & 2-Year \\
$\begin{array}{l}\text { Basal area }\left(\mathrm{m}^{2} .\right. \\
\left.\text { ha }^{-1}\right)\end{array}$ & $30.3 \pm 6.49 \mathrm{a}$ & $25.3 \pm 5.53 \mathrm{a}$ & $28.5 \pm 4.32 \mathrm{a}$ & $0.23 \pm 0.12 \mathrm{~b}$ \\
\hline Canopy cover (\%) & $92.8 \pm 2.17 \mathrm{a}$ & $90.3 \pm 1.49 \mathrm{a}$ & $87.5 \pm 3.11 \mathrm{a}$ & $16.3 \pm 2.21 \mathrm{~b}$ \\
\hline $\begin{array}{l}\text { Vegetation height } \\
\text { of trees (m) }\end{array}$ & $14.9 \pm 1.1 \mathrm{a}$ & $7.6 \pm 0.5 \mathrm{~b}$ & $12.8 \pm 2.1 \mathrm{a}$ & $1.59 \pm 0.3 \mathrm{c}$ \\
\hline $\begin{array}{l}\text { Tree density (ind. } \\
\text { ha-1) }\end{array}$ & $365 \pm 37 \mathrm{a}$ & $285 \pm 27 \mathrm{~b}$ & $385 \pm 22 \mathrm{a}$ & $28 \pm 8 \mathrm{c}$ \\
\hline $\begin{array}{l}\text { Saplings density } \\
\text { (ind. ha }\end{array}$ & $400 \pm 72 \mathrm{a}$ & $775 \pm 59 \mathrm{~b}$ & $1,125 \pm 89 \mathrm{c}$ & $100 \pm 11 \mathrm{~d}$ \\
\hline $\begin{array}{l}\text { Species richness } \\
\text { (tree and non- } \\
\text { tree) }\end{array}$ & $44 \pm 5 \mathrm{a}$ & $60 \pm 8 \mathrm{~b}$ & $45 \pm 4 \mathrm{a}$ & $20 \pm 1 \mathrm{c}$ \\
\hline
\end{tabular}




\section{Data Analysis}

For all vegetation attributes, we calculated the mean values per study site $(n=3)$. Differences among sites were tested with non-parametric ANOVA (Kruskal Wallis test), multiple comparisons between pairs were made with the Bonferroni method. The related p-values were computed and compared to the level of significance of 0.05 (see González-Alday et al., 2008).
Jaccard's dissimilarity index was calculated among the data sets of the community and the pool of planted species, to compare and analyze the similarity of the floristic composition between the study sites. The clustering method was the complete linkage algorithm (Suganuma et al., 2014). Furthermore, to compare vegetation composition among study sites, the Venn diagram was used, and Principal Component Analysis (PCA) was performed using the relative cover of each species.

A

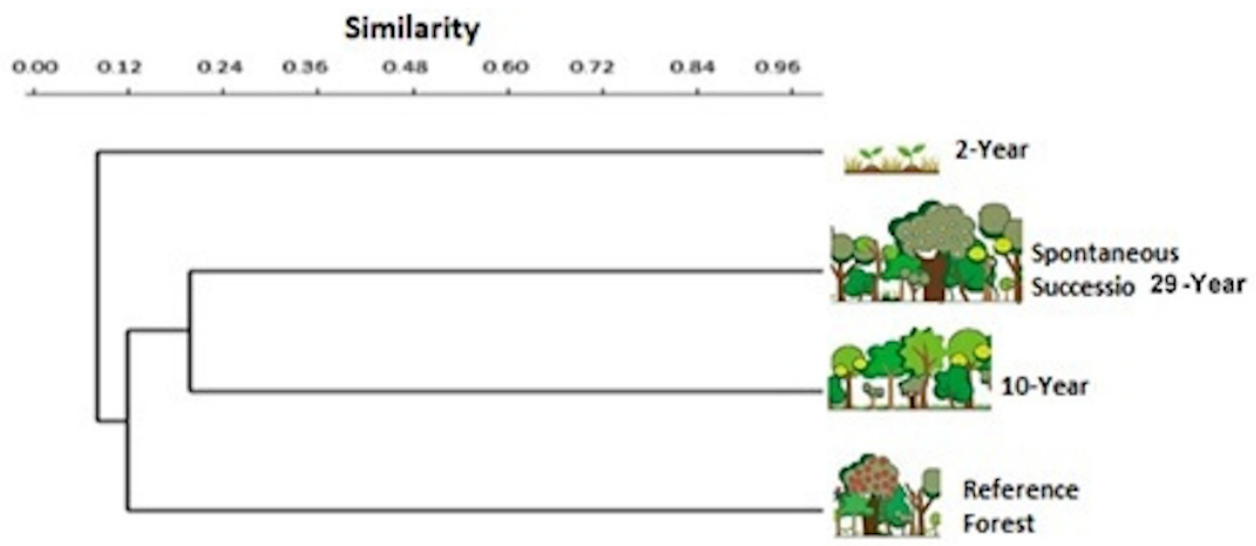

B

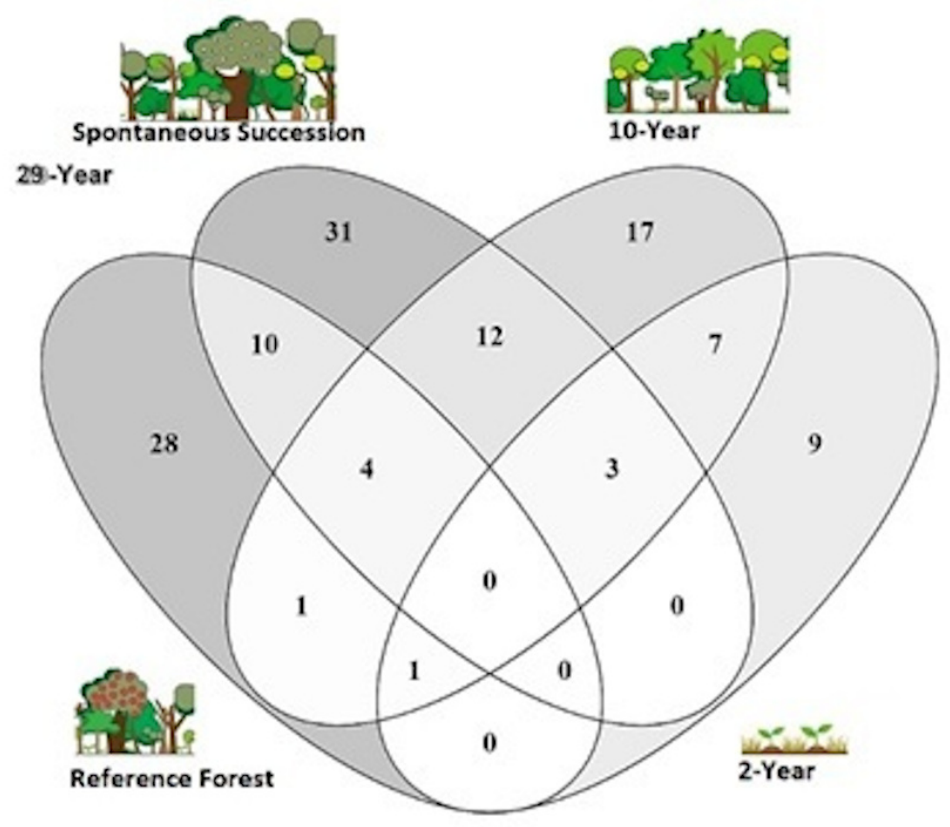

Figure 2. (A) Species composition similarity among sites evaluated for vegetation recovery after surface mining, in northeastern Antioquia, Colombia, according to Jaccard's dissimilarity index. (B) Venn diagram showing species distribution on two technically reclaimed sites of different ages (2 and 10 years old), a spontaneous succession site, and the reference forest. 
All statistical analyses were carried out using R software (R Core Team, 2014).

\section{Results}

We sampled a total of 167 species, across 93 saplings and 424 trees distributed in 62 genera, and $37 \mathrm{fa}-$ milies (Appendix 1). The most abundant families were Leguminosae with 18 species (14.5\%), Poaceae with 11 species $(8.9 \%)$ and, Moraceae with 10 species $(8.1 \%)$. The most abundant genera were Ficus (Moraceae) with 9 species $(9.4 \%$ ) and Cyperus (Cyperaceae) with 4 species $(4.2 \%)$. The vegetation attributes were markedly lower in the 2-year-old site. The basal area, canopy cover, and vegetation height of trees were much higher in RF, and they differed statistically from the 2-year-old site. The density of saplings was significantly higher in the 10 -year-old site. The total species richness of the community in the SS was significantly greater than at the other study sites (Table 1). Particularly, the species richness of the community at the 10 -year-old site is composed of planted species (59\%), in addition to immigrant species from the seed sources in the vicinity $(41 \%)$.
Similarity among sites was very low (Figure 2A), because of the low number of species planted in the technical reclamation sites and the high number of species in the SS. The SS and 10-year-old sites shared 19 species, making them the most similar sites, followed by the RF and SS, which shared 14 species. The 2-year-old site was characterized by the planted seedlings and the species Mimosa pigra. In particular, M. pigra corresponded to $33 \%$ of individuals sampled at the 2-year-old site. The SS forest and the 2-year-old site only shared 3 species (Figure 2B).

The smallest diameter class $(1-5 \mathrm{~cm})$ was the least abundant class in all of the study sites. For the RF, SS, and 2-year-old sites, the diameter class 5-20 $\mathrm{cm}$ was the most abundant. Only, the 10-year-old technical reclamation site had the higher numbers of individuals in the largest diameter class $(>20 \mathrm{~cm})$. Moreover, no large trees were found at the youngest site (2-year-old technical reclamation site; Figure 3).

The PCA showed that the first two components explained $91.41 \%$ of the variation among all study sites. This analysis revealed a gradient of land-cover types from 2-year-old site to the spontaneous succession and reference forests.

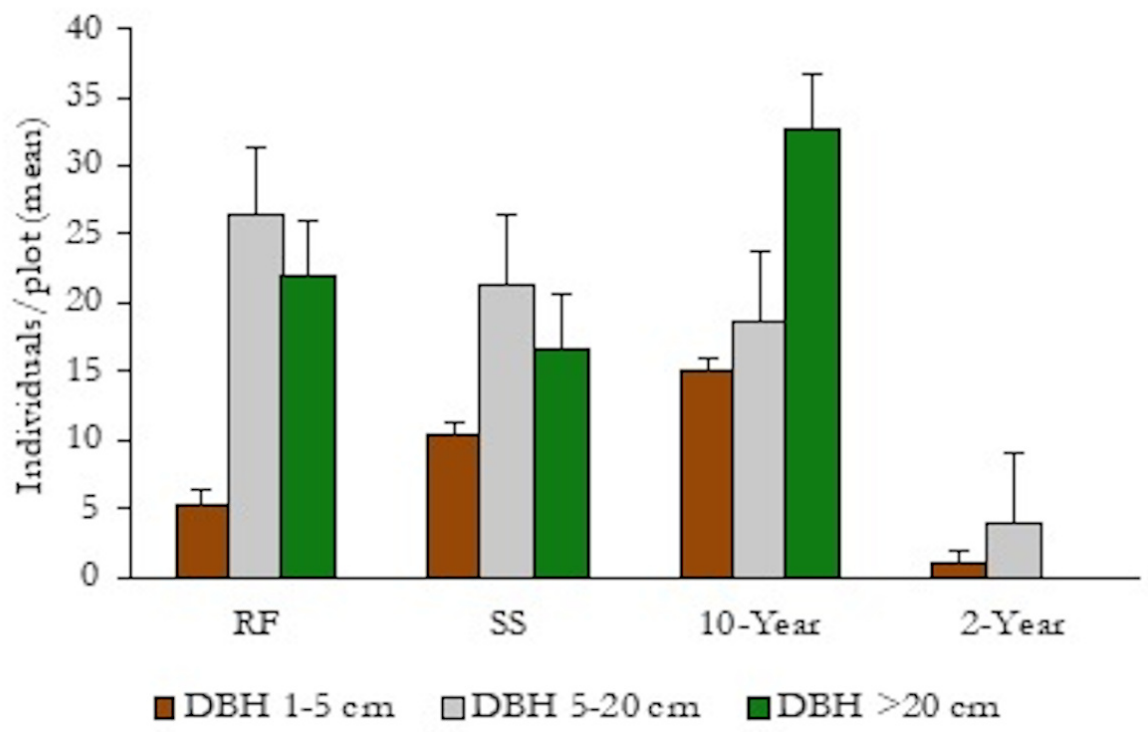

Figure 3. Number of tree individuals per diameter class (mean \pm standard error, $n=3)$ per plot $(1000 \mathrm{~m} 2)$ in areas recovering after surface mining, in northeastern Antioquia, Colombia. The areas include two technically reclaimed sites of different ages (2 and 10 years old), a spontaneous succession site (SS), and the reference forest (RF). 
The technical reclamation sites were separated from the RF and SS, due to lower species composition and simpler vegetation structure evidenced in the technical reclaimed forest. The RF and SS forests were more similar, sharing species such as Spondias mombin, Bursera simaruba, Cecropia peltata and Pseudobombax septenatum (Figure 4). As expected, the planted species dominated the 10-year-old technically reclaimed forest, and the pioneer species M. pigra characterized the 2-year-old reclaimed forest.

\section{Discussion}

To ensure the comparison between the study areas, we made great efforts so that our plots location had the least environmental variability, as recommended (Martínez-Ruiz et al., 2001). However, since most forest restoration efforts in the region have not been planned, it was not possible to find comparable sites to follow the chronosequence approach, where similar restoration activities are simultaneously performed over time. Our study case is based on within-site replication. We underscore that future investigations comparing spontaneous succession or technical reclamation approach, should compare multiple sites of different ages; also, these restoration approaches would need to be replicated and, ideally, the sites would be on similar soil types and ages. Although the environmental variability could be a problem during the research, the space-for-time substitution method (Pickett, 1989) with the multivariate analysis gives an option to overcome this problem.

We found that the ecological outcomes in spontaneous succession and technical reclamation are markedly different in vegetation structure and composition. After 10 years, most of the vegetation attributes (e. g., basal area, canopy cover, vegetation height, tree density, and species richness) were similar between the RF and technically reclaimed sites.

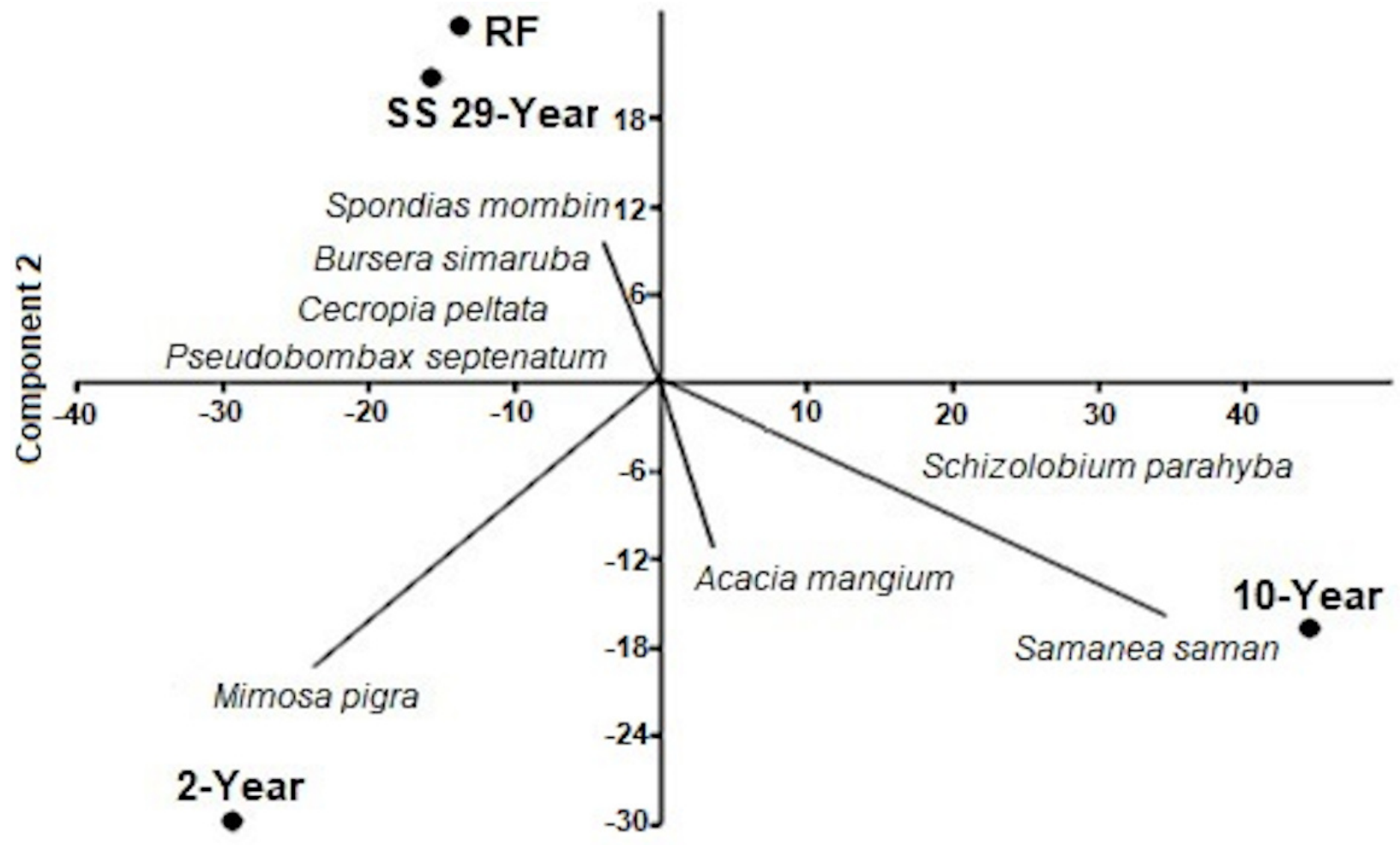

Component 1

Figure 4. Principal component analysis results, based on the relative cover of each species by study area, in areas recovering after surface mining, in northeastern Antioquia, Colombia. Reference forest (RF), spontaneous succession (SS), and two technically reclaimed sites of different ages ( 2 and 10 years old). 
However, the species composition is still distant from the RF. This low similarity was attributed to the pioneer species (e. g., C. peltata, Chromolaena odorata, Lantana camara, M. pigra, Mimosa pudica and Oxycaryum cubense) sampled in the technically reclaimed forests. Although these pioneers species are considered as invasive in tropical areas in Africa and Asia (IUCN/ SCC, 2020), for disturbed areas in America they are highly important to generate ecological conditions, especially shade, which promotes the establishment of late secondary species from the adjacent forest fragments (Rodrigues et al., 2004; Chambi-Legoas et al., 2021). On the other hand, to increase the diversity in the forests undergoing restoration, recently, Mineros S.A. has enriched the reforestation plantations through planting more native shrubs and tree species (e. g., Prioria copaifera, Senna bacillaris, and Pterocarpus sp.; Mineros S.A., 2019).

Our RF and SS sites with more advanced successional stages showed higher values for vegetation attributes. The finding of a significantly greater species richness at the SS forest is in line with several studies, suggesting that the spontaneous succession approach provides a valuable contribution to nature conservation and ecosystem services (Baasch et al., 2012; Gould, 2012; Prach \& Hobbs, 2008). This result comes as no surprise, because the RF has remained intact for a long time, and the SS has been 29 years under natural regeneration after abandonment, whereas technically reclaimed forests have a shorter time ( 2 and 10 years) in the successional vegetation process. Another possible explanation for the different outputs between technical reclamation and spontaneous succession is the initial soil condition at each site (Martínez-Ruiz \& Marrs, 2007; Lozano-Baez et al., 2019). At the SS forest, the soil might have had better initial conditions, which stimulated the potential recovery of the site and facilitated the recruitment of new tree species (Rodrigues et al., 2009). These soil conditions resulted from different technical processes; for example, at the SS forest, only one dredge was used during mining operations, and the alluvium material was dug at shallow depths (less than $20 \mathrm{~m}$ ). In the cases of the 2 and 10 year old forest, the alluvium material extraction used two dredges and reached depths of 20-30 m (Villa \& Tobón, 2012) Thus, initial silt, clay, and gravel proportions were different among study sites. Valois-Cuesta (2016) found that the collection of sand and gravel in large mounds (the main material produced by mining in Chocó) does not promote the early natural revegetation of areas affected by alluvial gold and platinum mining.
In the case of the 2-year-old technically reclaimed forest, the vegetation was characterized by pioneer species resistant to adverse conditions. This result is related to the early successional stage of the site, where the canopy openings allow more light input (García et al., 2016). Despite the extreme conditions caused by alluvial gold mining, our results show that technical reclamation taking place at El Bagre significantly increased the vegetation attributes after 10 years, reaching values similar to the RF. This result can be attributed to the fast-growth of the planted species. Specially, the exotic species A. mangium was introduced to Colombia at the beginning of the 1990s; however, the silvicultural and management aspects have been poorly studied in the country (Torres \& Del Valle, 2007; Valois-Cuesta, 2016). Castellanos and León (2010), estimated an annual fine litter production of $10.4 \mathrm{Mg} \mathrm{ha}^{-1}$ in A. mangium plantations that are 12 years old, established on a waste deposit resulting from small-scale mining in northeastern Antioquia. Valois-Cuesta (2016) found that the abundant litter cover that $A$. mangium produces on the soil of mines generates a physical barrier limiting the formation of the seed bank of native species, which coupled with the fact that mines are environments with compacted soils, they make the early natural revegetation of abandoned and revegetated mines with $A$. mangium scarce and slow. A. mangium is a promising species for reclaiming mining degraded soils, but the species also has the potential to cause negative impacts when it becomes invasive (Koutika \& Richardson, 2019; IUCN/ SCC, 2020). Thus, it is important that future studies in Colombia consider the ecology of the species and their impacts on biodiversity and ecosystem function. Recent research in our study area has shown that $S$. parahyba plantations that are 9 years old evidenced higher abundance, species density, and diversity than $A$. mangium plantations, indicating that $S$. parahyba plantations can provide a better habitat and soil conditions to seedling establishment (Quiceno, 2017). In our study case, the density of saplings in the mix-plantation (e. g., A. mangium, S. parahyba, and S. saman) with 10 years old was significantly higher than the other study sites; this result is attributed to the high density of $C$. odorata, which represented $30 \%$ of the sapling in this site. Since C. odorata seeds germinate preferentially in open areas and their seedlings do not survive in natural shade conditions (Awanyo et al., 2011), it may be suggested that this species will be substituted by late species in the course of ecological succession. In order to confirm this tendency, we recommend monitoring the vegetation at longer time intervals. 
Overall, several studies around the world have suggested the spontaneous succession approach in post-mining landscapes, as long as adjacent (semi) natural vegetation can act as seed sources for mined sites (Martínez-Ruiz \& Marss, 2007; Martínez-Ruiz et al., 2007; Prach \& Hobbs, 2008; Baasch et al., 2012; Šebelíková et al., 2016). For the study area, future research should examine the restoration potential of the surrounding vegetation and its influence in the process of spontaneous succession. Also, it is important to realize that the technical reclamation of areas degraded by mining needs to enhance the use of native species, which have the potential to attract fauna to facilitate the recovery process (Gastauer et al., 2018). For instance, the native species Bixa orellana planted on waste deposits created by small-scale mining in the municipality of Condoto (Chocó) has shown a fast growth without fertilization (Ayala et al., 2008). In the same region other native tree species that have been proposed to recover degraded mining land are; Croton killipianus, Vismia baccifera, Vismia macrophylla, Miconia reducens, Cespedesia spathulata, Cecropia hispidissima and C. peltata (Valois-Cuesta \& Martínez-Ruiz, 2017; Valois-Cuesta et al., 2017).

The main environmental challenge in northeastern Antioquia is to protect the forest areas that have naturally regenerated or have never been affected by mining operations. A common problem in the study area is that forests that have a long process of natural regeneration can be mined again by informal miners. This is a complex environmental problem, considering that $86.7 \%$ of the gold mining in Colombia is performed without the environmental license of the government, and only $1.5 \%$ of the mining production has an environmental management or restoration plan (Betancur-Corredor et al., 2018). Agroforestry practices that include local populations can be a positive alternative to protect the reforestation plantations after alluvial gold mining. It is equally important that the mining process does not leave material that can be re-exploited, which can be achieved using appropriate technology.

In conclusion, the hypothesis that technical reclamation in previous alluvial gold-exploitations after 10 years can recover the vegetation structure and composition was not supported. After ten years of technical reclamation, there are positive results for the vegetation structure, but the vegetation composition is still far from the reference forest. The spontaneous succession approach can result in a well-established forest in about 29 years, especially if the initial soil conditions are favorable, if (semi) natural vegetation exists in the surrounding areas and human disturbances (e. g., cattle grazing and small-scale mining) are avoided during the recuperation process.

\section{Acknowledgments}

This research was funded by the Colombian Ministry of Science (grant no. 848), "Vicerrectoría de Investigaciones, Extensión y Proyección Social" of Universidad del Atlántico, FONDECYT (project 11191021) and Mineros S.A. We thank the editor and two anonymous reviewers for their constructive comments. We also thank Ana Carolina Moreno Cárdenas, Carlos Pardo Zarache, Milena Moreno, Iván González Garzón and Alberto Ramírez González for their support during this work. PM thanks the support of the Vicerrectoría de Investigación, Universidad de La Frontera.

\section{References}

Anderson, P. M. L. \& Hoffman, M. T. (2007). The impacts of sustained heavy grazing on plant diversity and composition in lowland and upland habitats across the Kamiesberg mountain range in the Succulent Karoo, South Africa. Journal of Arid Environments, 70(4), 686-700. https:/ / doi.org/10.1016/j.jaridenv.2006.05.017

Arias-Escobar, M. A. \& Barrera-Cataño, J. I. (2007). Caracterización florística y estructural de la vegetación vascular en áreas con diferente condición de abandono en la cantera soratama, localidad de Usaquén, Bogotá. Universitas Scientiarum, 12, 25-45.

Awanyo, L., Attuah, E. M. \& McCarron, M. Rehabilitation of forest-savannas in Ghana: The impacts of land use, shade, and invasive species on tree recruitment. Applied Geography, 31(1), 181-190. https:/ / doi.org/10.1016/j.apgeog.2010.04.002

Ayala, M. H. J., Mosquera, P. J. \& Murillo, M. W. I. (2008). Evaluación de la adaptabilidad de la acacia (Acacia mangium Wild), y bija (Bixa orellana) en áreas degradadas por la actividad minera aluvial en el Chocó biogeográfico, Condoto, Chocó, Colombia. Bioetnia, 5(2), 115-123.

Baasch, A., Kirmer, A. \& Tischew, S. (2012). Nine years of vegetation development in a postmining site: Effects of spontaneous and assisted site recovery. Journal of Applied Ecology, 49(1), 251-260. https://doi.org/10.1111/j.1365-2664.2011.02086.x

Betancur-Corredor, B., Loaiza-Usuga, J. C., Denich, M. \& Borgemeister, C. (2018). Gold mi- 
ning as a potential driver of development in Colombia: Challenges and opportunities. Journal of Cleaner Production, 199, 538-553. https:// doi.org/10.1016/j.jclepro.2018.07.142

Bridge, G. (2004). Contested terrain: Mining and the environment. Annual Review of Environment and Resources, 29(1), 205-259. https:/ / doi.org/10.1146/annurev.energy.28.011503.163434

Canfield, R. (1941). Application of line interception method in sampling range vegetation. Journal of Forestry, 39, 388-394. https:/ / doi.org/10.1093/jof/39.4.388

Castellanos, J. \& León, J. D. (2010). Caída de hojarasca y dinámica de nutrientes en plantaciones de Acacia mangium (Mimosaceae) de Antioquia, Colombia. Acta Biológica Colombiana, 15(2), 289-308.

Chambi-Legoas, R., Ortega, R. D. R., de Márquez, F. F., Peña, V. J., Zeballos, P. P. A., Marcelo-Peña, J. L. \& Rother, D. C. (2021). Natural regeneration after gold mining in the Peruvian Amazon: Implications for restoration of tropical forests. Frontiers in Forest and Global Change, 4, 1-10. https:/ / doi.org/10.3389/ffgc.2021.594627

Chaves, R. B., Durigan, G., Brancalion, P. H. S. \& Aronson, J. (2015). On the need of legal frameworks for assessing restoration projects success: New perspectives from São Paulo State (Brazil): Legal instruments for assessing restoration. Restoration Ecology, 23(6), 754-759. https://doi.org/10.1111/rec.12267

Dominguez-Haydar, Y. \& Armbrecht, I. (2011). Response of ants and their seed removal in rehabilitation areas and forests at El Cerrejón coal mine in Colombia. Restoration Ecology, 19(201), 178-184. https:// doi.org/10.1111/j.1526-100X.2010.00735.x

Fırıncioğlu, H. K., Seefeldt, S. S. \& Şahin, B. (2007). The effects of long-term grazing exclosures on range plants in the Central Anatolian region of Turkey. Environmental Management, 39(3), 326-337. https:/ / doi.org/10.1007/s00267-005-0392-y

Garcia, L. C., Hobbs, R. J., Ribeiro, D. B., Tamashiro, J. Y., Santos, F. A. M. \& Rodrigues, R. R. (2016). Restoration over time: Is it possible to restore trees and non-trees in high-diversity forests? Applied Vegetation Science, 19(4), 655-666. https:// doi.org/10.1111/avsc.12264

Gastauer, M., Silva, J. R., Caldeira, C. F. J., Ramos, S. J., Souza F. P. W. M., Furtini, A. E. N. \& Siqueira, J. O. (2018). Mine land rehabilitation: Modern ecological approaches for more sustainable mining. Journal of Cleaner Production, 172, 1409-1422. https:/ / doi.org/10.1016/j.jclepro.2017.10.223
González-Alday, J., Marrs, R. \& Martínez-Ruiz, C. (2008). The influence of aspect on the early growth dynamics of hydroseeded species in coal reclamation areas. Applied Vegetation Science, 11, 405-412. https:/ / doi.org/10.3170/2008-7-18497

González-González, A., Clerici, N. \& Quesada, B. (2021). Growing mining contribution to Colombian. Environmental Research Letters, in press, 1-13. https:/ / doi.org/10.1088/1748-9326/abfcf8deforestation

Gould, S. F. (2012). Comparison of post-mining rehabilitation with reference ecosystems in Monsoonal eucalypt woodlands, Northern Australia. Restoration Ecology, 20(2), 250-259. https:/ / doi.org/10.1111/j.1526-100X.2010.00757.x

IUCN/SCC. (2020). Invasive species specialist group. Global invasive species database. Retrieved from http:/ / www.iucngisd.org/gisd/ (accessed 12 April 2021).

Jones, H. P., Jones, P. C., Barbier, E. B., Blackburn, R. C., Rey-Benayas, J. M, Holl, K. D., McCrackin, M., Meli, P., Montoya, D., \& Moreno, M. (2018). Restoration and repair of earth's damaged ecosystems. Proceedings of the Royal Society B: Biological Sciences, 285(1873), 1-8. https://doi.org/10.1098/rspb.2017.2577

Koutika, L. S. \& Richardson, D. M. (2019). Acacia mangium Willd: Benefits and threats associated with its increasing use around the world. Forest Ecosystems, 6(1), 1-13. https://doi.org/10.1186/s40663-019-0159-1

Lozano-Baez, S. E., Cooper, M., Ferraz, S. F. B., Rodrigues, R. R., Castellini, M. \& Di Prima, S. (2019). Recovery of soil hydraulic properties for assisted passive and active restoration: Assessing historical land use and forest structure. Water, 11(1), 1-18. https:/ / doi.org/10.3390/w11010086

Martínez-Ruiz, C., Fernández Santos, B. \& Gómez-Gutiérrez, J. M. (2001). Effects of substrate coarseness and exposure on plant succession in uranium mining wastes. Plant Ecology, 155(1), 79-89. https:// doi.org/10.1023/A:1013208305393

Martínez-Ruiz C., Fernández-Santos B., Fernández-Gómez, MJ. \& Putwain P.D. (2007). Natural and man-induced revegetation on mining wastes: Changes in the floristic composition at early succession. Ecological Engineering, 30(3), 286-294 https:// doi.org/10.1016/j.ecoleng.2007.01.014

Martínez-Ruiz, C. \& Marrs, R.H. (2007). Some factors affecting successional change on uranium mine wastes: Insights for ecological restoration. Applied Vegetation Science, 10, 333-342. https:/ / doi.org/10.1111/j.1654-109X.2007.tb00432.x 
MinerosS.A (2019).Memoria de sostenibilidad Retrieved from

https:/ / mineros.com.co/Sostenibilidad/Gesti\%-

C3\%B3n-Ambiental (accessed 12 April 2021).

Ministerio del Trabajo. (2013). Perfil productivo del Municipio El Bagre. Insumo para el diseño de las estrategias y alternativas para la generación de empleo a las víctimas de la violencia, Medellín. Programa de las Naciones Unidas para el Desarrollo (PNUD).

Ministry of Mines and Energy. (2019). Colombia alluvial gold exploitation evidences from remote sensing, 2018. United Nations Office on Drugs and Crime.

Paynter, Q. (2005). Evaluating the impact of a biological control agent carmenta mimosa on the woody wetland weed Mimosa pigra in Australia: Mimosa biological control. Journal of Applied Ecology, 42(6), 1054-1062. https:/ / doi.org/10.1111/j.1365-2664.2005.01105.x

Prach, K. \& Hobbs, R. J. (2008). Spontaneous succession versus technical reclamation in the restoration of disturbed sites. Restoration Ecology, 16(3), 363-366. https:/ / doi.org/10.1111/j.1526-100X.2008.00412.x

Pickett S.T.A. (1989). Space-for time substitution as an alternative to long-term studies. In: Likens G.E. (ed.). Long-term Studies in Ecology: Approaches and Alternatives. Springer-Verlag.

Quiceno, M. D. E. (2017). Efecto de las plantaciones de Acacia mangium Willd. y Schizolobium parahyba (Vell.) S.F. Blake sobre la trayectoria sucesional de la vegetación, en áreas de explotación minera a cielo abierto. (Tesis de Maestría). Universidad Nacional de Colombia.

R Core Team. (2014). R: A language and environment for statistical computing. Viena, Austria: R Foundation for Statistical Computing.

Ramírez, G. \& Rangel-Ch., J. O. (2019). Sucesión vegetal en áreas de minería a cielo abierto en el bosque pluvial tropical del departamento del Chocó, Colombia. Revista de la Academia Colombiana de Ciencias Exactas, Físicas y Naturales, 43(169), 673-688. https:// doi.org/10.18257/raccefyn.896

Rodrigues, R. R., Lima, R. A. F., Gandolfi, S. \& Nave, A. G. (2009). On the restoration of high diversity forests: 30 Years of experience in the Brazilian Atlantic Forest. Biological Conservation, 142(6), 1242-1251. https:/ / doi.org/10.1016/j.biocon.2008.12.008

Rodrigues, R. R., Martins, S. V. \& de Barros, L. C. (2004). Tropical rain forest regeneration in an area degraded by mining in Mato Grosso State, Brazil. Forest Ecology and Management, 190, 323-333. https:/ / doi:10.1016/j.foreco.2003.10.023

Šebelíková, L., Řehounková, K. \& Prach, K. (2016). Spontaneous revegetation vs. forestry recla- mation in post-mining sand pits. Environmental Science and Pollution Research, 23(14), 1-11. https:/ / doi.org/10.1007/ s11356-015-5330-9

Sigcha, F., Pallavicini, Y., Camino, M.J. \& Martínez-Ruiz, C. (2018). Effects of short-term grazing exclusion on vegetation and soil in early succession of a Subhumid Mediterranean reclaimed coal mine. Plant and Soil, 426(1), 197-209. https:/ / doi.org/10.1007/ s11104-018-3629-2

Stohlgren, T. J., Falkner, M. B. \& Schell, L. D. (1995). A Modified-Whittaker Nested Vegetation Sampling Method. Vegetatio, 117(2), 113-121. https:// doi.org/10.1007/BF00045503

Stohlgren, T. J., Bull, K. A. \& Otsuki, Y. (1998). Comparison of rangeland vegetation sampling techniques in the central grasslands. Journal of Range Management, 51(2), 164-172. https:// doi.org/10.2307/4003202

Suganuma, M. S., Assis, G. B. \& Durigan, G. (2014). Changes in plant species composition and functional traits along the successional trajectory of a restored patch of Atlantic Forest. Community Ecology, 15(1), 27-36. https:/ / doi.org/10.1556/ComEc.15.2014.1.3

Thomas, E. (2014). Forest devastated by mining is reborn. Nature, 511(7508), 155-155. https://doi.org/10.1038/511155d

Torres V. D. A. \& Del Valle, J. I. (2007). Growth and yield modelling of Acacia mangium in Colombia. New Forests, 34(3), 293-305. https:/ / doi.org/10.1007/s11056-007-9056-5

Tropek, R., Kadlec, T., Hejda, M., Kocarek, P., Skuhrovec, J., Malenovsky, I., Vodka, S. Spitzer, L., Banar, P. \& Konvicka. M. (2012). Technical reclamations are wasting the conservation potential of postmining sites. A case study of black coal spoil dumps. Ecological Engineering, 43, 13-18.

Valois-Cuesta, H. (2016). Sucesión primaria y ecología de la revegetación de selvas degradadas por minería en El Chocó, Colombia: Bases para su restauración. (Tesis de doctorado). Universidad de Valladolid.

Valois, H. \& Martínez-Ruiz, C. (2016). Vulnerability of native forests in the Colombian Chocó: Mining and biodiversity conservation. Bosque, 37(2), 295-305. https:/ / doi.org/10.4067/S071792002016000200008

Valois-Cuesta, H. \& Martínez-Ruiz, C. (2017). Especies vegetales colonizadoras de áreas perturbadas por la minería en bosques pluviales tropicales del Chocó, Colombia. Biota Colombiana, 18(1), 87-103. https://doi.org/10.21068/c2017.v18n01a7 
Valois-Cuesta, H., Martínez-Ruiz, C. \& Urrutia-Rivas, Y. (2017). Formación del banco de semillas durante la revegetación temprana de áreas afectadas por la minería en un bosque pluvial tropical del Chocó, Colombia. Revista de Biología Tropical, 65(1), 393-404. https:/ / doi.org/10.15517/rbt.v65i1.23190

Viani, R. A. G., Barreto, T. E., Farah, F. T., Rodrigues, R. R. \& Brancalion, P. H. S. (2018). Monitoring young tropical forest restoration sites: How much to measure? Tropical Conservation Science, 11, 1-9. https://doi.org/10.1177/1940082918780916
Villa, J. A. \& Tobón, C. (2012). Modeling hydrologic dynamics of a created wetland, Colombia. Ecological Engineering, 40, 173-182. https:// doi.org/10.1016/j.ecoleng.2011.12.005

Zhen, Q., Ma, W., Li, M., He, H., Zhang, X. \& Wang, Y. (2015). Effects of vegetation and physicochemical properties on solute transport in reclaimed soil at an opencast coal mine site on the Loess Plateau, China. CATENA, 133, 403-411. https:// doi.org/ 10.1016/j.catena.2015.06.009 
Appendix 1. Plant species sampled in areas recovering after surface mining, in northeastern Antioquia, Colombia. Reference forest, Spontaneous Succession, 10 and 2 years old reclaimed forests.

\begin{tabular}{|c|c|c|c|c|}
\hline Species & Reference forest & $\begin{array}{l}\text { Spontaneous } \\
\text { Succession }\end{array}$ & 10 -Years old & 2-Years old \\
\hline \multicolumn{5}{|l|}{ Amaranthaceae } \\
\hline $\begin{array}{r}\text { Cyathula } \\
\text { achyranthoides } \\
\text { (Kunth) Moq. }\end{array}$ & & & $\mathrm{X}$ & \\
\hline \multicolumn{5}{|l|}{ Anacardiaceae } \\
\hline $\begin{array}{r}\text { Ochoterenaea } \\
\text { colombiana F.A. } \\
\text { Barkley }\end{array}$ & & & $\mathrm{X}$ & \\
\hline Spondias mombin L. & $\mathrm{X}$ & $\mathrm{X}$ & $\mathrm{X}$ & \\
\hline $\begin{array}{r}\text { Spondias radlkoferi } \\
\text { Donn. Sm. }\end{array}$ & $\mathrm{X}$ & $\mathrm{X}$ & & \\
\hline $\begin{array}{r}\text { Tapirira guianensis } \\
\text { Aubl. }\end{array}$ & $\mathrm{X}$ & & & \\
\hline \multicolumn{5}{|l|}{ Annonaceae } \\
\hline $\begin{array}{r}\text { Xylopia aromatica } \\
\text { (Lam.) Mart }\end{array}$ & & $\mathrm{X}$ & & \\
\hline \multicolumn{5}{|l|}{ Apocynaceae } \\
\hline Mandevilla sp. & & & & $\mathrm{X}$ \\
\hline \multicolumn{5}{|l|}{ Araceae } \\
\hline $\begin{array}{r}\text { Monstera adansonii } \\
\text { Schott }\end{array}$ & $\mathrm{X}$ & $\mathrm{X}$ & $\mathrm{X}$ & \\
\hline Monstera sp. & $\mathrm{X}$ & & & \\
\hline $\begin{array}{c}\text { Syngonium } \\
\text { podophyllum Schott }\end{array}$ & $\mathrm{X}$ & & & \\
\hline \multicolumn{5}{|l|}{ Araliaceae } \\
\hline $\begin{array}{r}\text { Schefflera morototoni } \\
\text { (Aubl.) Maguire, } \\
\text { Steyerm. \& Frodin }\end{array}$ & & $\mathrm{X}$ & & \\
\hline \multicolumn{5}{|l|}{ Bignoniaceae } \\
\hline $\begin{array}{r}\text { Jacaranda copaia } \\
\text { (Aubl.) D. Don }\end{array}$ & $\mathrm{X}$ & & & \\
\hline $\begin{array}{r}\text { Jacaranda hesperia } \\
\text { Dugand }\end{array}$ & $\mathrm{X}$ & & & \\
\hline $\begin{array}{l}\text { Tabebuia rosea } \\
\text { (Bertol.) A. DC. }\end{array}$ & & & $\mathrm{X}$ & \\
\hline \multicolumn{5}{|l|}{ Bixaceae } \\
\hline $\begin{array}{r}\text { Cochlospermum } \\
\text { orinocense (Kunth) } \\
\text { Steud. }\end{array}$ & $\mathrm{X}$ & & & \\
\hline
\end{tabular}


Species

Reference forest

X

X

Cordia alliodora

(Ruiz \& Pav.) Oken

Cordia bogotensis

Benth.

\begin{tabular}{|c|c|c|}
\hline Burseraceae & & \\
\hline $\begin{array}{r}\text { Bursera simaruba } \\
\text { (L.) Sarg. }\end{array}$ & $\mathrm{X}$ & $\mathrm{X}$ \\
\hline $\begin{array}{r}\text { Tetragastris } \\
\text { panamensis (Engl.) } \\
\text { Kuntze } \\
\end{array}$ & & $\mathrm{X}$ \\
\hline Cannabaceae & & \\
\hline $\begin{array}{r}\text { Trema micrantha }(\mathrm{L} .) \\
\text { Blume }\end{array}$ & $\mathrm{X}$ & \\
\hline Clusiaceae & & \\
\hline $\begin{array}{r}\text { Clusia lineata } \\
\text { (Benth.) Planch. \& } \\
\text { Triana }\end{array}$ & & $\mathrm{X}$ \\
\hline
\end{tabular}

Combretaceae

Terminalia catappa $\mathrm{L}$.

Compositae

Chromolaena odorata

(L.) R.M. King \& H.

Rob.

\begin{aligned} & \hline Costaceae \\ & \hline Costus $\mathrm{sp}. \mathrm{X} \\ &$\hline Cucurbitaceae $\mathrm{X} \\ &$\hline Momordica charantia \\ & L. \\ & \hline\end{aligned}

Cyperaceae

Cyperus haematodes

Endl.

Cyperus luzulae (L.)

Retz.

\section{Cyperus odoratus L.}

Cyperus simplex

Kunth

Fimbristylis

dichotoma (L.) Vahl

Oxycaryum cubense

(Poepp. \& Kunth)

Palla
Spontaneous

Succession

10-Years old

2-Years old

\section{$\mathrm{X}$}

$\mathrm{X}$

X

X $\quad$ X

X

X

$\mathrm{X}$

X

X

X

$\mathrm{X}$ 


\begin{tabular}{|c|c|c|c|c|}
\hline Species & Reference forest & $\begin{array}{l}\text { Spontaneous } \\
\text { Succession }\end{array}$ & 10-Years old & 2-Years old \\
\hline $\begin{array}{r}\text { Scleria gaertneri } \\
\text { Raddi }\end{array}$ & & & $\mathrm{X}$ & \\
\hline \multicolumn{5}{|l|}{ Dilleniaceae } \\
\hline $\begin{array}{r}\text { Davilla kunthii A. } \\
\text { St.-Hil. }\end{array}$ & & $\mathrm{X}$ & & \\
\hline \multicolumn{5}{|l|}{ Euphorbiaceae } \\
\hline $\begin{array}{r}\text { Acalypha diversifolia } \\
\text { Jacq. }\end{array}$ & $\mathrm{X}$ & $\mathrm{X}$ & & \\
\hline $\begin{array}{r}\text { Alchornea } \\
\text { costaricensis Pax \& } \\
\text { K. Hoffm. }\end{array}$ & & $\mathrm{X}$ & & \\
\hline $\begin{array}{r}\text { Alchornea latifolia } \\
\text { Sw. }\end{array}$ & $\mathrm{X}$ & & & \\
\hline $\begin{array}{r}\text { Euphorbia dioeca } \\
\text { Kunth. }\end{array}$ & & & & $\mathrm{X}$ \\
\hline $\begin{array}{r}\text { Sapium glandulosum } \\
\text { (L.) Morong }\end{array}$ & & & $\mathrm{X}$ & \\
\hline \multicolumn{5}{|l|}{ Hypericaceae } \\
\hline $\begin{array}{l}\text { Vismia baccifera (L.) } \\
\text { Triana \& Planch. }\end{array}$ & $\mathrm{X}$ & & & \\
\hline \multicolumn{5}{|l|}{ Lauraceae } \\
\hline $\begin{array}{r}\text { Cinnamomum } \\
\text { triplinerve (Ruiz \& } \\
\text { Pav.) Kosterm. }\end{array}$ & & $\mathrm{X}$ & & \\
\hline \multicolumn{5}{|l|}{ Leguminosae } \\
\hline $\begin{array}{r}\text { Acacia mangium } \\
\text { Willd. }\end{array}$ & & & $\mathrm{X}$ & $\mathrm{X}$ \\
\hline $\begin{array}{r}\text { Albizia carbonaria } \\
\text { Britton }\end{array}$ & $\mathrm{X}$ & & & \\
\hline $\begin{array}{r}\text { Andira inermis (W. } \\
\text { Wright) Kunth ex } \\
\text { DC. }\end{array}$ & & $\mathrm{X}$ & & \\
\hline Cassia grandis L. f. & & $\mathrm{X}$ & & \\
\hline $\begin{array}{r}\text { Desmodium } \\
\text { adscendens (Sw.) DC. }\end{array}$ & & & $\mathrm{X}$ & \\
\hline $\begin{array}{r}\text { Desmodium } \\
\text { tortuosum (Sw.) DC. }\end{array}$ & & & $X$ & \\
\hline Dipteryx alata Vogel & & $\mathrm{X}$ & $\mathrm{X}$ & \\
\hline $\begin{array}{r}\text { Enterolobium } \\
\text { cyclocarpum (Jacq.) } \\
\text { Griseb. }\end{array}$ & & $\mathrm{X}$ & $\mathrm{X}$ & \\
\hline Erythrina fusca Lour. & & & $\mathrm{X}$ & \\
\hline
\end{tabular}




\begin{tabular}{|c|c|c|c|c|}
\hline Species & Reference forest & $\begin{array}{l}\text { Spontaneous } \\
\text { Succession }\end{array}$ & 10 -Years old & 2-Years old \\
\hline $\begin{array}{r}\text { Erythrina rubrinervia } \\
\text { Kunth. }\end{array}$ & $\mathrm{X}$ & $X$ & & \\
\hline $\begin{array}{l}\text { Lonchocarpus } \\
\text { macrophyllus } \text { Kunth. }\end{array}$ & $\mathrm{X}$ & & & \\
\hline Machaerium sp. & & & $\mathrm{X}$ & \\
\hline Mimosa pigra L. & & & $\mathrm{X}$ & $\mathrm{X}$ \\
\hline Mimosa pudica L. & & & $\mathrm{X}$ & $\mathrm{X}$ \\
\hline $\begin{array}{r}\text { Samanea saman } \\
\text { (Jacq.) Merr. }\end{array}$ & & $\mathrm{X}$ & $\mathrm{X}$ & $\mathrm{X}$ \\
\hline $\begin{array}{r}\text { Schizolobium } \\
\text { parahyba (Vell.) S.F. } \\
\text { Blake. }\end{array}$ & $\mathrm{X}$ & & $\mathrm{X}$ & $\mathrm{X}$ \\
\hline $\begin{array}{r}\text { Senna bacillaris } \\
\text { (L. f.) H.S. Irwin \& } \\
\text { Barneby }\end{array}$ & $\mathrm{X}$ & & & \\
\hline \multicolumn{5}{|l|}{ Malpighiaceae } \\
\hline $\begin{array}{r}\text { Bunchosia } \\
\text { hartwegiana } \text { Benth. }\end{array}$ & & $\mathrm{X}$ & & \\
\hline \multicolumn{5}{|l|}{ Malvaceae } \\
\hline Abutilon sp. & & & $\mathrm{X}$ & \\
\hline $\begin{array}{r}\text { Ceiba pentandra (L.) } \\
\text { Gaertn. }\end{array}$ & $\mathrm{X}$ & & & \\
\hline Corchorus hirtus L. & & & & $\mathrm{X}$ \\
\hline $\begin{array}{r}\text { Guazuma ulmifolia } \\
\text { Lam. }\end{array}$ & $\mathrm{X}$ & & & \\
\hline $\begin{array}{l}\text { Luehea seemannii } \\
\text { Triana \& Planch. }\end{array}$ & $\mathrm{X}$ & & & \\
\hline $\begin{array}{r}\text { Pseudobombax } \\
\text { septenatum (Jacq.) } \\
\text { Dugand }\end{array}$ & & $\mathrm{X}$ & & \\
\hline \multicolumn{5}{|l|}{ Marantaceae } \\
\hline $\begin{array}{r}\text { Calathea lutea } \\
\text { Schult. }\end{array}$ & $\mathrm{X}$ & & & \\
\hline Calathea sp. & $X$ & & & \\
\hline \multicolumn{5}{|l|}{ Melastomataceae } \\
\hline $\begin{array}{r}\text { Clidemia hirta (L.) D. } \\
\text { Don. }\end{array}$ & $\mathrm{X}$ & & & \\
\hline $\begin{array}{r}\text { Clidemia octona } \\
\text { (Bonpl.) L.O. } \\
\text { Williams. }\end{array}$ & $\mathrm{X}$ & & & \\
\hline $\begin{array}{r}\text { Miconia lonchophylla } \\
\text { Naudin. }\end{array}$ & & $\mathrm{X}$ & & \\
\hline $\begin{array}{l}\text { Miconia serrulata } \\
\text { (DC.) Naudin. }\end{array}$ & & $\mathrm{X}$ & $\mathrm{X}$ & \\
\hline
\end{tabular}




\begin{tabular}{|c|c|c|c|c|}
\hline Species & Reference forest & $\begin{array}{l}\text { Spontaneous } \\
\text { Succession }\end{array}$ & 10-Years old & 2-Years old \\
\hline \multicolumn{5}{|l|}{ Meliaceae } \\
\hline Cedrela odorata L. & $\mathrm{X}$ & & & \\
\hline Trichilia pallida $\mathrm{Sw}$. & & $\mathrm{X}$ & & \\
\hline \multicolumn{5}{|l|}{ Moraceae } \\
\hline $\begin{array}{r}\text { Artocarpus altilis } \\
\text { (Parkinson) Fosberg }\end{array}$ & $\mathrm{X}$ & & & \\
\hline Ficus citrifolia Mill. & & $X$ & & \\
\hline $\begin{array}{r}\text { Ficus dendrocida } \\
\text { Kunth. }\end{array}$ & & $\mathrm{X}$ & & \\
\hline $\begin{array}{r}\text { Ficus donnell-smithii } \\
\text { Standl. }\end{array}$ & & $\mathrm{X}$ & & \\
\hline Ficus insipida Willd. & & $\mathrm{X}$ & $\mathrm{X}$ & \\
\hline $\begin{array}{r}\text { Ficus nymphaeifolia } \\
\text { Mill. }\end{array}$ & & $\mathrm{X}$ & & \\
\hline $\begin{array}{r}\text { Ficus obtusifolia } \\
\text { Kunth. }\end{array}$ & & $\mathrm{X}$ & & \\
\hline Ficus schippii Standl. & & $\mathrm{X}$ & & \\
\hline Ficus sp. & & $\mathrm{X}$ & & \\
\hline Ficus tonduzii Standl. & $X$ & & & \\
\hline \multicolumn{5}{|l|}{ Myrtaceae } \\
\hline Psidium guajava L. & & & $\mathrm{X}$ & \\
\hline \multicolumn{5}{|l|}{ Nyctaginaceae } \\
\hline $\begin{array}{r}\text { Guapira costaricana } \\
\text { (Standl.) Woodson. }\end{array}$ & & $\mathrm{X}$ & $\mathrm{X}$ & \\
\hline \multicolumn{5}{|l|}{ Ochnaceae } \\
\hline $\begin{array}{r}\text { Cespedesia } \\
\text { spathulata (Ruiz \& } \\
\text { Pav.) Planch. }\end{array}$ & & $\mathrm{X}$ & $\mathrm{X}$ & \\
\hline \multicolumn{5}{|l|}{ Onagraceae } \\
\hline $\begin{array}{l}\text { Ludwigia octovalvis } \\
\text { (Jacq.) P.H. Raven. }\end{array}$ & & & $\mathrm{X}$ & $\mathrm{X}$ \\
\hline \multicolumn{5}{|l|}{ Osmundaceae } \\
\hline $\begin{array}{r}\text { Osmundastrum } \\
\text { cinnamomeum (L.) C. } \\
\text { Presl } \\
\end{array}$ & $\mathrm{X}$ & $\mathrm{X}$ & & \\
\hline \multicolumn{5}{|l|}{ Passifloraceae } \\
\hline $\begin{array}{r}\text { Passiflora } \\
\text { quadrangularis } \mathrm{L} .\end{array}$ & & $\mathrm{X}$ & $\mathrm{X}$ & \\
\hline $\begin{array}{r}\text { Passiflora vitifolia } \\
\text { Kunth. }\end{array}$ & $\mathrm{X}$ & & & \\
\hline Phyllanthaceae & & & & \\
\hline
\end{tabular}




\begin{tabular}{|c|c|c|c|c|}
\hline Species & Reference forest & $\begin{array}{l}\text { Spontaneous } \\
\text { Succession }\end{array}$ & 10 -Years old & 2-Years old \\
\hline $\begin{array}{r}\text { Margaritaria nobilis } \\
\text { L. F. }\end{array}$ & $\mathrm{X}$ & & & \\
\hline \multicolumn{5}{|l|}{ Piperaceae } \\
\hline Piper auritum Kunth. & & $\mathrm{X}$ & $X$ & \\
\hline Piper peltatum $\mathrm{L}$. & & $\mathrm{X}$ & $\mathrm{X}$ & \\
\hline $\begin{array}{r}\text { Piper tuberculatum } \\
\text { Jacq. }\end{array}$ & & & $\mathrm{X}$ & \\
\hline \multicolumn{5}{|l|}{ Poaceae } \\
\hline $\begin{array}{r}\text { Andropogon bicornis } \\
\mathrm{L} .\end{array}$ & & & & $\mathrm{X}$ \\
\hline $\begin{array}{r}\text { Echinochloa colona } \\
\text { (L.) Link }\end{array}$ & $\mathrm{X}$ & $\mathrm{X}$ & & \\
\hline $\begin{array}{r}\text { Echinochloa } \\
\text { polystachya (Kunth) } \\
\text { Hitchc. }\end{array}$ & & $\mathrm{X}$ & $\mathrm{X}$ & $\mathrm{X}$ \\
\hline $\begin{array}{r}\text { Homolepis glutinosa } \\
\text { (Sw.) Zuloaga \& } \\
\text { Soderstr. }\end{array}$ & & & & $\mathrm{X}$ \\
\hline $\begin{array}{r}\text { Panicum } \\
\text { polygonatum Schrad. }\end{array}$ & & $\mathrm{X}$ & $\mathrm{X}$ & \\
\hline $\begin{array}{r}\text { Paspalum conjugatum } \\
\text { P.J. Bergius } \\
\end{array}$ & & & $\mathrm{X}$ & $\mathrm{X}$ \\
\hline $\begin{array}{r}\text { Sporobolus cubensis } \\
\text { Hitchc. }\end{array}$ & & & & $\mathrm{X}$ \\
\hline \multicolumn{5}{|l|}{ Polypodiaceae } \\
\hline $\begin{array}{r}\text { Microgramma } \\
\text { persicariifolia } \\
\text { (Schrad.) C. Presl }\end{array}$ & $\mathrm{X}$ & $\mathrm{X}$ & & \\
\hline $\begin{array}{r}\text { Microgramma reptans } \\
\text { (Cav.) A.R. Sm. }\end{array}$ & & $\mathrm{X}$ & & \\
\hline $\begin{array}{r}\text { Niphidium } \\
\text { crassifolium (L.) } \\
\text { Lellinger } \\
\end{array}$ & $\mathrm{X}$ & $\mathrm{X}$ & & \\
\hline \multicolumn{5}{|l|}{ Pteridaceae } \\
\hline $\begin{array}{r}\text { Adiantum } \\
\text { tetraphyllum Humb. } \\
\text { \& Bonpl. ex Willd. }\end{array}$ & $\mathrm{X}$ & $\mathrm{X}$ & & \\
\hline \multicolumn{5}{|l|}{ Rubiaceae } \\
\hline $\begin{array}{r}\text { Palicourea croceoides } \\
\text { Desv. ex Ham. }\end{array}$ & & $X$ & & \\
\hline $\begin{array}{r}\text { Pentagonia } \\
\text { macrophylla Benth. }\end{array}$ & $\mathrm{X}$ & & & \\
\hline $\begin{array}{r}\text { Picramnia latifolia } \\
\text { Tul. }\end{array}$ & $\mathrm{X}$ & & & \\
\hline
\end{tabular}


Species

Reference forest
Spontaneous

Succession
10-Years old

2-Years old

Psychotria buchtienii

(H.J.P. Wink1.)

Standl.

\begin{tabular}{|c|c|c|c|c|}
\hline $\begin{array}{r}\text { Spermacoce alata } \\
\text { Aubl. }\end{array}$ & & & $\mathrm{X}$ & $\mathrm{X}$ \\
\hline \multicolumn{5}{|l|}{ Rutaceae } \\
\hline Citrus sp. & & $\mathrm{X}$ & & \\
\hline $\begin{array}{r}\text { Zanthoxylum fagara } \\
\text { (L.) Sarg. }\end{array}$ & & & $\mathrm{X}$ & \\
\hline \multicolumn{5}{|l|}{ Salicaceae } \\
\hline $\begin{array}{r}\text { Casearia arguta } \\
\text { Kunth. }\end{array}$ & $\mathrm{X}$ & $\mathrm{X}$ & $\mathrm{X}$ & \\
\hline $\begin{array}{r}\text { Tetrathylacium } \\
\text { johansenii Standl. }\end{array}$ & & $\mathrm{X}$ & & \\
\hline \multicolumn{5}{|l|}{ Sapindaceae } \\
\hline $\begin{array}{r}\text { Serjania } \\
\text { membranacea Splitg. }\end{array}$ & & $\mathrm{X}$ & & \\
\hline \multicolumn{5}{|l|}{ Sapotaceae } \\
\hline $\begin{array}{r}\text { Pouteria torta (Mart.) } \\
\text { Radlk. }\end{array}$ & $\mathrm{X}$ & & & \\
\hline \multicolumn{5}{|l|}{ Selaginellaceae } \\
\hline $\begin{array}{r}\text { Selaginella flagellata } \\
\text { Spring. }\end{array}$ & & $\mathrm{X}$ & & \\
\hline \multicolumn{5}{|l|}{ Siparunaceae } \\
\hline $\begin{array}{r}\text { Siparuna sessiliflora } \\
\text { (Kunth) A. DC. }\end{array}$ & & $\mathrm{X}$ & & \\
\hline \multicolumn{5}{|l|}{ Solanaceae } \\
\hline Solanum hirtum Vahl & & $\mathrm{X}$ & & \\
\hline \multicolumn{5}{|l|}{ Tectariaceae } \\
\hline $\begin{array}{r}\text { Tectaria } \\
\text { draconoptera (D.C. } \\
\text { Eaton) Copel. }\end{array}$ & $\mathrm{X}$ & & $\mathrm{X}$ & \\
\hline \multicolumn{5}{|l|}{ Thelypteridaceae } \\
\hline $\begin{array}{r}\text { Thelypteris } \\
\text { arborescens (Humb. } \\
\text { \& Bonpl. ex Willd.) } \\
\text { C.V. Morton }\end{array}$ & $\mathrm{X}$ & & & \\
\hline \multicolumn{5}{|l|}{ Urticaceae } \\
\hline Cecropia peltata L. & $\mathrm{X}$ & $\mathrm{X}$ & $\mathrm{X}$ & \\
\hline \multicolumn{5}{|l|}{ Verbenaceae } \\
\hline Lantana camara L. & & $\mathrm{X}$ & & \\
\hline Lantana trifolia $\mathrm{L}$. & & $\mathrm{X}$ & & \\
\hline
\end{tabular}


Sergio Esteban Lozano-Baez

Universidad del Atlantico

Puerto Colombia, Colombia sergiolozano1391@gmail.com

https:/ / orcid.org/0000-0001-6170-1095

\section{José Ignacio Barrera-Cataño}

Pontificia Universidad Javeriana

Bogotá, Colombia

barreraj@javeriana.edu.co

https:/ / orcid.org/0000-0002-7999-7610

\section{Ricardo Ribeiro Rodrigues}

Universidad de São Paulo

Piracicaba, Brasil

rrresalq@usp.br

https:/ / orcid.org/0000-0003-4818-0736

\section{Yamileth Domínguez-Haydar}

Universidad del Atlantico

Puerto Colombia, Colombia

yamilethdominguez@mail.uniatlantico.edu.co

https:/ / orcid.org/0000-0002-0774-8391

\section{Paula Meli}

Universidad de la Frontera

Temuco, Chile

paulameli@ufrontera.cl

https:/ / orcid.org/0000-0001-5390-7552
Forest restoration after alluvial gold mining can recover vegetation structure. A case study in Colombia

Citación del artículo: Lozano-Baez, S. E., Barrera-Cataño, J. I., Rodrigues, R. R., Domínguez-Haydar, Y. \& Meli, P. (2022). Forest restoration after alluvial gold mining can recover vegetation structure. A case study in Colombia. Biota Colombiana, 23(1), e969.

https:/ / doi.org/10.21068/2539200X.969

Recibido: 10 de mayo 2021

Aceptado: 1 de septiembre 2021 